\title{
Characteristics of Atrial Fibrillation Based On Age, Sex, and Etiology
}

\author{
Barizatul Husniyah¹, Bambang Herwanto ${ }^{2 \star}$, Noor Idha Handayani ${ }^{3}$
}

\begin{abstract}
${ }^{1}$ Faculty of Medicine, Universitas Airlangga, Surabaya, Indonesia.
${ }^{2}$ Department of Cardiology and Vascular Medicine, Faculty of Medicine, Universitas Airlangga, Surabaya, Indonesia. ${ }^{3}$ Department of Physical Medicine and Rehabilitation, Faculty of Medicine, Universitas Airlangga, Surabaya, Indonesia.
\end{abstract}

\section{A B S T R A C T}

Introduction: Atrial fibrillation (AF) is one type of arrhythmia that occurs frequently to patients in the last decade. AF patients have five times higher risk to stroke and death, and they also have two times higher risk compared to others. A correct selection of governance in AF could result in better prognosis of the patients. The aim of this study was to explain AF of the outpatients in Department of Cardiology of Dr. Soetomo General Hospital Surabaya in February 2018, so that it can detect early AF and prevent further advanced complications.

Methods: This research was descriptive method design. The population and sample of this study included all of the patients who had AF and came to out-patient care in Department of Cardiology of Dr. Soetomo General Hospital Surabaya in February 2018. This research was real-time total sampling and was analyzed descriptively.

Results: In this study, 60 samples which were suitable to the criteria were gained with the numbers of 25 males (41.7\%) and 35 females (58.3\%). AF attacked more patients in age 51-60 years old (31.7\%). The most common etiology of AF is rheumatic heart disease $(60 \%)$.

Conclusion: Most of AF patients in this study were 51-60 years old, female, and were caused by rheumatic heart disease. With the lack information, it still needed further studies with more complete data for better accuracy.

@ 2020 JUXTA: Jurnal IImiah Mahasiswa Kedokteran Universitas Airlangga.

Available at https://e-journal.unair.ac.id/juxta

*Correspondence: dr_bambangher@yahoo.com

JUXTA: Jurnal IImiah Mahasiswa Kedokteran Universitas Airlangga

p-ISSN: 1907-3623; e-ISSN: 2684-9453

DOI: 10.20473/juxta.V11122020.86-89

Open access under Creative Commons Attribution-ShareAlike 4.0 International License (CC-BY-SA)

\section{ARTICLE INFO}

\author{
Article history: \\ Received 8 June 2020 \\ Received in revised form 2 July \\ 2020
}

Accepted 7 July 2020

\section{Keywords:}

Atrial Fibrillation,

Age,

Sex,

Etiology,

Risk Factor. 


\section{Introduction}

Heart disease has the highest mortality. Atrial fibrillation (AF) is the most common arrhythmia that affects patients in the last decade. The prevalence of this disease is increasing rapidly and is often associated with serious diseases such as heart failure, dementia, stroke, etc. ${ }^{1}$ Research in Europe shows that AF prevalence varies from age and sex. As much as $0.12 \%-0.16 \%$. AF is in those who are less than 49 years old, $3.7 \%-4.2 \%$ in those aged $60-70$ years old, and at $10 \%-17 \%$ in those aged 80 years old or more. In addition, $A F$ is more common in men, with a male to female ratio of 1.2:1. AF events range between 0.21 and 0.41 per 1,000 people/year. Although the prevalence is relatively lower in Asia than in the west, the prognostic impact on stroke and death caused by AF in Asia is comparable to that in the west. ${ }^{2}$

AF is a typical supraventricular tachyarrhythmia with uncoordinated atrial activation which has a negative effect on the mechanical function of the atrium. On an EKG, the characteristic of AF is that there is no consistency of $P$ waves, and is replaced by vibrational waves (fibrillation) which have variations in amplitude, shape, and duration. ${ }^{3}$ Although untreated AF has two times higher risk of death in heart disease and has five times higher risk of stroke, many patients do not realize that $A F$ is a serious condition. ${ }^{4}$

Greater prevalence of AF is found in elderly people, male, and in hospitalized patients with clinical conditions such as high blood pressure (hypertension), heart failure, coronary artery disease, heart valve disease, diabetes mellitus, and chronic kidney disease. AF has various symptoms. Starting from shortness of breath, palpitations, chest pain, and others. Thus, early detection of AF is needed so that the patients can get treatment quickly and prevent complications that will later be obtained. The increased prevalence of $A F$ in addition to being associated with aging and conditions that support $A F$ can also detect silent AF better. Improved detection and governance of AF is expected to reduce morbidity and mortality due to cardiovascular disease. ${ }^{5}$ The things mentioned above form the background of the author to examine the description of AF of outpatients in Department of Cardiology of Dr. Soetomo General Hospital Surabaya in February 2018, so that it can detect early AF and prevent further advanced complications.

\section{Methods}

This study was a descriptive study. This study was performed in February using real total sampling. The population and sample studied were all patients with AF who came to the outpatient clinic in Heart Disease Installation at Dr. Soetomo General Hospital Surabaya in February 2018. The variables used in this study were age, sex, and etiology of patients with AF. This study obtained data from medical records of patients who came in February on the same day as the patient visited.

This study received ethical approval from Research and Development Department of Dr. Soetomo General
Hospital Surabaya. Data collected were age, sex, and ethiology of AF. The data were entered into Microsoft Office Excel and statistically analyzed by SPSS IBM 20.

\section{Results}

In this study, a total of 60 patients were diagnosed with AF.

Table 1. Characteristics of atrial fibrillation patients.

\begin{tabular}{lcc}
\multicolumn{1}{c}{ Variable } & Frequency & Percentage \\
\hline Age Category & 1 & \\
$\leq 20$ years old & 2 & $1.7 \%$ \\
$21-30$ years old & 6 & $10.0 \%$ \\
$31-40$ years old & 17 & $28.3 \%$ \\
$41-50$ years old & 19 & $31.7 \%$ \\
$51-60$ years old & 11 & $18.3 \%$ \\
$61-70$ years old & 4 & $6.7 \%$ \\
$>70$ years old & & \\
Gender & 25 & $41.7 \%$ \\
Male & 35 & $58.3 \%$ \\
Female & & \\
\hline Etiology & 3 & $5.0 \%$ \\
Coronary Artery & & \\
Disease & 36 & $60.0 \%$ \\
Rheumatic Heart & & \\
Disease & 9 & $15.0 \%$ \\
Hypertension & 12 & $20.0 \%$ \\
Others & & \\
\hline
\end{tabular}

Table 1 shows the characteristics of AF patients seen by age, sex and etiology. The incidence of AF in this study was greatest in groups with the age range of 51-60 years old $(31.7 \%)$. The average patient with AF in this study was $52.7 \pm 12.5$ years old. The youngest age was 20 years old, while the oldest age was 80 years old. The sex of AF patients in February 2018 was mostly women, as many as 35 people $(58.3 \%)$. In this study. the comparison of male and female AF patients was 1:1.4. The etiology of AF were rheumatic heart disease $(60 \%)$, other diseases $(20 \%)$, hypertension (15\%), and coronary heart disease $(5 \%)$ as the smallest causes for AF in this study.

Other etiologies for AF were Atrial Septal Defect, atherosclerosis, and Lone AF. As many as 10 cases of AF arose without the underlying cause (Lone AF). Whereas the etiology of non-heart disease was not found in this study.

\section{Discussion}

AF has been found in the last decade and has caused a variety of comorbidities. In this study, AF was found in the age range of 51-60 years old. This results of this study are in line with Safrina's (2014) study which showed that of 45 atrial fibrillation patients in Dr. Soetomo General Hospital Surabaya in 2013, it obtained the largest age group of patients in the age range of 40-59 years old as many as 22 patients (48.9\%) and the age most affected by AF at the age of $<25$ years old, as many as 2 people $(4.4 \%){ }^{6}$ Similar results were also found in the study at Mamata General 
Hospital in India, where the highest age distribution of patients with atrial fibrillation was the 50-60 years old age group of 16 people $(32.65 \%) .{ }^{7}$ Different results were obtained in the research conducted at Regional Hospital of East Belitung. This study showed that the highest age distribution was the age group of 60-75 years old with a total of 25 people $(36.2 \%){ }^{8}$ A research performed at Bharatpur Chitwan in Nepal also showed different things, that the highest age group with AF ranged from 30-39 years old $(24.26 \%) .{ }^{9}$ The results of the research by Dharmawan, et al. (2017) were different because the number of samples studied was different and the duration of the study used was 2014-2016 inpatient care at East Belitung Hospital. ${ }^{8}$ Research by Gautam, et al. (2012) was also different because most patients who came were young adults. ${ }^{9}$ Increased age can lead to atrophy of the heart muscle, which interferes with the conduction and contraction of the atrium and triggers the remodeling and dilatation of the atrium. Increasing age can also increase the risk of developing $\mathrm{AF}$ with other underlying cardiovascular diseases. ${ }^{10}$ Nevertheless, this is not reflected in Indonesia, because the average life expectancy in Indonesia is not more than 70 years. ${ }^{11}$

This study shows that the sex of patients who had AF in Dr. Soetomo hospital in February 2018 was dominated by women, with a percentage of $58.3 \%$. This research is in line with the research conducted by Gautam, et al. (2012) in Bharatpur Chitwan in Nepal which showed that the incidence of $\mathrm{AF}$ is more common in women, which was 74 people $(54.41 \%) .{ }^{9}$ The research which was also conducted at Dr. Soetomo General Hospital Surabaya in January 2013-December 2013 obtained 45 patients with 28 women (62.2\%). ${ }^{6} \mathrm{~A}$ research in one of the tertiary hospitals in India from January 2015 to June 2016 found that the incidence of $\mathrm{AF}$ was dominated by women, with a percentage of $60 \% .{ }^{12}$ Nevertheless, this research is not in line with the research conducted by Adeyana, et al. (2017), Berisso MZ, et al. (2014), and Friberg, et al. (2013) which showed that men dominated the occurrence of AF. ${ }^{13-15}$

Men dominate the occurrence of AF because in men, the expression of excessive ion channel repolarization can accelerate atrial repolarization and the mechanism of in and out of the ion causes the diameter of the male left atrium to be greater than that of women, so the risk of AFis high in men. ${ }^{16}$ Nevertheless, in women symptomatic symptoms are more visible, because women have a faster heart rhythm. Canadian Registry of Atrial Fibrillation (CARAF) states that women experience recurrence of $\mathrm{AF}$ more often, although there is no difference in EKG. ${ }^{17}$

In this study, of the 60 etiologies of AF, it was found that rheumatic heart disease was the biggest cause of $\mathrm{AF}$ in 36 cases $(60 \%)$. This study is in line with the research in Bharatpur Chitwan Cardiology Department in Nepal in 2010 which explained that rheumatic heart disease was the most etiology of AF at $33.09 \%$, unknown AF at $23.52 \%$, idiopathic (Lone AF) at $21.32 \%$, coronary heart disease at $16.18 \%$, and hypertension at $8.82 \% .^{9}$ This study is also in line with a research in one of the tertiary hospitals in India from January 2015 to June 2016 where the highest etiology of AF was rheumatic heart disease (40\%), CAD (21.8\%), and hypertension (12.7\%). ${ }^{12}$

However, this study is not in line with a research in 2 tertiary hospitals in Lithuania in November 2013-May 2014, showing that of 515 patients. the highest etiology was hypertension $(85.8 \%)$, heart failure $(77.9 \%)$, and heart disease coronary (51.8\%). Sex, age, and etiology of AF can increase patient's alertness to detect early onset AF later in life. Thus, patients can quickly go to the nearest doctor if they have AF symptoms and these risk factors. ${ }^{18}$

In rheumatic heart disease, the valve muscle is damaged which can cause ventricular filling to be disrupted. This causes the diameter of the left atrium to expand and produce a fast and irregular ectopic wave. ${ }^{19}$ As age increases, the cell's density and elasticity decrease along the valve. Collagen synthesis also decreases, thus the heart valves are easily degraded. ${ }^{20}$ Patients with AF have a five-fold and twice the risk of stroke and death. ${ }^{14}$ Although untreated AF has two times higher risk of death in heart disease and has five times higher risk of stroke, many patients do not realize that $A F$ is a serious condition. ${ }^{4}$

\section{Conclusion}

Characteristics of most AF patients in this study were 51-60 years old, female, and were caused by rheumatic heart disease. Further studies are needed to evaluate risk factor approach strategies.

\section{CONFLICT OF INTEREST}

The author stated there is no conflict of interest in this study.

\section{REFERENCES}

1. Munger TM, Wu LQ and Shen WK. Atrial Fibrillation. Journal of Biomedical Research. 2014; 28: 1-17.

2. Murakoshi N and Aonuma K. Epidemiology of Arrhythmias and Sudden Cardiac Death in Asia. Circulation Journal : Official Journal of the Japanese Circulation Society. 2013; 77: 2419-31.

3. Bellet S. Clinical Disorders of the Heart Beat. 3rd ed. Philadelphia: Lea \& Febiger, 1971.

4. Nishimura RA, Otto CM, Bonow RO, et al. 2017 AHA/ACC Focused Update of the 2014 AHA/ACC Guideline for the Management of Patients With Valvular Heart Disease: A Report of the American College of Cardiology/American Heart Association Task Force on Clinical Practice Guidelines. Circulation. 2017; 135: e1159e95.

5. Authors/Task Force m, Erbel R, Aboyans V, et al. 2014 ESC Guidelines on the Diagnosis and Treatment of Aortic Diseases: Document Covering Acute and Chronic Aortic Diseases of the Thoracic and Abdominal Aorta of the Adult The Task Force for the Diagnosis and Treatment of Aortic Diseases of the European Society of Cardiology (ESC). European Heart Journal. 2014; 35: 2873-926.

6. Safrina U. Studi Penggunaan Antikoagulan pada Pasien Penyakit Atrial Fibrilasi (Penelitian di Instalasi Rawat Inap Jantung dan Pembuluh Darah RSUD Dr. Soetomo 
Surabaya). Surabaya: Fakultas Farmasi Universitas Airlangga, 2014.

7. Rao V D, Reddy M R, K S, Prakash B R, Prasad A S and Prasad S G. To Study the Prevalence and Clinical Profile of Chronic Atrial Fibrillation in Hospitalized Patients. Journal of Health and Allied Sciences NU. 2014; 04: 01720.

8. Dharmawan M, Mikhael R, Marthadinata F, Lustoyo L and Kawengian C. Profil Fibrilasi Atrium di RSUD Kabupaten Belitung Timur tahun 2014-2016. Cermin Dunia Kedokteran. 2017; 44: 611-3.

9. Gautam M, Gautam S, Prasad S, Subramanyam G and Gautam U. A Study of the Clinical Profile of Atrial Fibrillation in a Tertiary Care Super-Specialty Referral Centre in Central Nepal. Journal of College of Medical SciencesNepal. 2013; 8.

10. Nabar A and Pathan I. Pathophysiology of Atrial Fibrillation - Current Concepts. Supplement to Journal of The Association of Physicians of India. India2016, p. 11-5. 11. Statistik BP. Subdirektorat Statistik Pendidikan dan Kesejahteraan Sosial. In: Statistik, (ed.). Jakarta: Badan Pusat Statistik, 2015, p. 19-24.

12. Rajge H, Thakkar M, Naik R and Ghanekar J. A Study on Etiology and Clinical Profile of Patients with Atrial Fibrillation. Indian Journal of Applied Research. 2017; 7: 635-8.
13. Wijaya C, Adeyana S and Haryadi H. Hubungan Kejadian Fibrilasi Atrium dengan Diameter Atrium Kiri pada Fibrilasi Atrium Valvular dan Fibrilasi Atrium Non-Valvular di RSUD Arifin Achmad. Jurnal IImu Kedokteran. 2017: 31 8.

14. Zoni-Berisso M, Lercari F, Carazza T and Domenicucci S. Epidemiology of Atrial Fibrillation: European perspective. Clin Epidemiol. 2014; 6: 213-20.

15. Friberg $L$ and Bergfeldt $L$. Atrial Fibrillation Prevalence Revisited. Journal of Internal Medicine. 2013; 274: 461-8.

16. Liu XK, Jahangir A, Terzic A, Gersh BJ, Hammill SC and Shen WK. Age- and Sex-Related Atrial Electrophysiologic and Structural Changes. The American Journal of Cardiology. 2004; 94: 373-5.

17. Kerr CR and Humphries K. Gender-Related Differences in Atrial Fibrillation. Journal of the American College of Cardiology. 2005; 46: 1307-8.

18. Račkauskas G, Zabiela V, Marinskis G, et al. Evaluation of Atrial Fibrillation Management and Cardiovascular Risk Profile in Atrial Fibrillation Patients: A Cross-Sectional Survey. Medicina (Kaunas, Lithuania). 2017; 53: 19-25.

19. Mohammed I. Atrial Fibrillation in Rheumatic Heart Disease - Clinical and Echocardiographic Study. 2004, p. 11-3.

20. Klein SL and Flanagan KL. Sex Differences in Immune Responses. Nature Reviews Immunology. 2016; 16: 62638. 